\title{
New records of millipedes (Diplopoda), mainly from bird nests, in European Russia
}

\author{
Новые находки многоножкек-диплопод (Diplopoda) в основном \\ из гнезА птиџ в европейской части России
}

\author{
Sergei I. Golovatch \& Aleksandr V. Matyukhin \\ С.И. Головач, А.В. Матюхин \\ Institute for Problems of Ecology and Evolution, Russian Academy of Sciences, Leninsky pr. 33, Moscow 119071 Russia. \\ Институт проблем экологии и эволюции РАН, Ленинский пр-т, 33, Москва 119071 Россия.
}

KEY WORDS: diplopods, faunistic records, bird nests, central Russia, southern Russia.

КЛЮЧЕВЫЕ СЛОВА: диплоподы, фаунистика, гнезда птиц, Центральная Россия, Южная Россия.

ABSTRACT. The first records of millipedes encountered in bird nests in European Russia are presented. Only a few (three) diplopod species appear to populate bird nests in central Russia, whereas in southern Russia the nidicolous fauna seems to be richer (at least six species), all being clearly related to the adjacent Caucasus. The diplopod Craspedosoma rawlinsi Leach, 1814 is new to the central Russian list, having been encountered active under snow in winter in a park in Moscow City.

РЕЗЮМЕ. Представлены первые находки дипопод в гнездах птиц из европейской части России. Оказывается, лишь несколько видов (три) населяют гнезда птиц в Центральной России, тогда как на юге страны нидиколы представлены богаче (по меньшей мере шесть видов) и все отчетливо связаны с соседним Кавказом. Вид Craspedosoma rawlinsi Leach, 1814 - новый для фауны Центральной России с находкой его в активном состоянии под снегом зимой в одном из парков Москвы.

\section{Introduction}

Millipedes, or Diplopoda, have long been recorded in bird nests [e.g. Schubart, 1934], but none of them is an obligate nidicole [Golovatch \& Kime, 2009]. In the most recent of the special surveys of the millipedes encountered in bird nests in Europe, 301 bird nests representing seven nest types and 40 bird species throughout Slovakia revealed 18 diplopod species from four orders, with Polyxenus lagurus (L.) and Proteroiulus fuscus (Am Stein) being the most common [Tajovský et al. 2001]. Concerning Russia, Polyxeni$\mathrm{da}$, as well as small/juvenile Polydesmida and Julida have been reported from bird nests and plumage in the southern part of the country [D. Krivolutsky, in litt.].

Millipede material, now housed in the collection of the Zoological Museum of the Moscow Stare Universi- ty, Russia, was mainly taken recently by one of us (AVM) in different parts of European Russia, chiefly from nests of several bird species. It forms the basis of the present note. Eventually this is the first faunistic publication concerning the millipedes occurring in bird nests in Russia.

Only material identified to the species level is referred to hereafter, while a few more records of closer unidentified species are omitted.

Taxonomic part

Order Julida

Family Blaniulidae

Nopoiulus kochii (Gervais, 1847)

MATERIAL. 4 우, Moscow City, Kuskovo Park, nests of Turdus pilaris, 4-5 m above ground-level, 29.06.2009; $1 \mathrm{O}^{7}, 12$ 우, same locality and habitat, 23.06.2010; $10 \sigma^{\top \top} \sigma^{7}, 18$ 우, Kalmyk Republic, Elista, vegetable garden, 15.06.2010; 29 ○ $\sigma^{\top}, 38$ 우, Rostov-on-Don Region, southern bank of Lake Manych-Gudilo, ca $46^{\circ} 20^{\prime} \mathrm{N}, 42^{\circ} 90^{\prime} \mathrm{E}$, under dry cattle dung, 08.2009, all leg. A. Matyukhin.

REMARKS. This ubiquitous species is especially common in various synanthropic habitats.

Family Nemasomatidae

Nemasoma caucasicum (Lohmander, 1932)

MATERIAL. $1 \sigma^{7}$, Stavropol Prov., Kislovodsk, nest of Turdus iliacus, 4-5 m above ground-level, 29.07.2005; 2 ○' $\sigma^{7}, 5$ 우, 1 juv., same locality and habitat, 28.08.2005; $1 \sigma^{7}, 1+13$ juv., same locality and habitat, $14.02 .2009 ; 5 \sigma^{\top}, 5$ of, 12 juv., same locality, nest of Turdus merula, 4-5 m above ground-level, 14.02.2009; all leg. A. Matyukhin.

REMARKS. This is a rather common Caucasian species, while the above records only slightly extend its distribution to the north. 
Family Julidae

Megaphyllum rossicum (Timotheew, 1897)

MATERIAL. $1+$, Stavropol Prov., Kislovodsk, nest of Turdus merula, 4-5 m above ground-level, 14.02.2009; 2 우, same locality and habitat, 14.07.2005; all leg. A. Matyukhin.

REMARKS. This species is very common throughout the forested steppe and, partly, steppe belts of Russia and the Ukraine, occurring also in the Crimea and the Caucasus Major.

\section{Megaphyllum brachyurum (Attems, 1899)}

MATERIAL. 19 , Stavropol Prov., Kislovodsk, nest of Turdus merula, 4-5 m above ground-level, 14.07.2005; $19 \sigma^{7} \sigma^{\top}, 30$ 우, Kalmyk Republic, Elista, vegetable garden, 15.06.2010; all leg. A. Matyukhin.

REMARKS. This highly common pan-Caucasian species shows a surprisingly wide range of ecological plasticity, often being encountered not only in humid forests (e.g. in Hyrcania, southeastern Azerbaijan), but also in dry, almost barren habitats of Daghestan Republic, Russia. The present record in a remote manmade biotope within the semi-desert belt of Kalmyk Repiblic only reinforces this observation.

Rossiulus kessleri (Lohmander, 1927)

MATERIAL. 1 juv., Stavropol Prov., Kislovodsk, nest of Troglodytes troglodytes on stump, 14.07.2005, leg. A. Matyukhin.

REMARKS. This species is very common throughout the forested steppe belt of Russia and the Ukraine, reaching central Byelorussia in the west (where it almost borders on the eastern range limit of $R$. vilnensis (Jawłowski, 1925) near Minsk) and Cisuralia (Chelyabinsk Region and Bashkortostan Republic) in the east. It also occurs high in the mountains of the central Caucasus Major (Kabardino-Balkaria and North Ossetia republics).

\section{Ommatoiulus sabulosus (Linnaeus, 1758)}

MATERIAL. $1 \sigma^{\top}, 4$ 90,1 juv., Peredelkino SW of Moscow City, nest of Parus major, 1-2 m above ground-level, 14.07.2005; 1 $\circ$, Zvenigorod Biological Station of Moscow State University, in birdhouse with Parus major nest, summer 1996, all leg. A. Matyukhin.

REMARKS. This pan-European species is very common throughout Eastern Europe, reaching Cisuralia (Perm and Chelyabinsk regions, as well as Bashkortostan Republic) in the east.

\section{Order Chordeumatida}

Family Craspedosomatidae

\section{Craspedosoma rawlinsi Leach, 1814}

MATERIAL. $5 \sigma^{\top} \sigma^{\top}, 4$ 오, Moscow City, Bitsevsky Park, pitfall trapping under snow, 15.12.2006, leg. R.A. Zakharov.

REMARKS: This seems to be a highly interesting record, the first in central Russia. The geographically closest encounters of this pan-European species concern Baltic states, Byelorussia and the Kaliningrad Region, Russia. That it has been reported so far inland and easterly is likely to reflect a recent introduction which is possibly related to global climate change. That is has been found active under snow in winter reinforces the known observations that many species of Chordeumatida are especially cold-resistant [e.g. Golovatch \& Kime, 2009].

Order Polydesmida

Family Polydesmidae

\section{Polydesmus inconstans Latzel, 1884}

MATERIAL. 2 90, 36 juv., Moscow City, Kuskovo Park, nest of Turdus pilaris, 4-5 m above ground-level, 25-29.06.2009; 1 q, same locality, nest of Turdus philomelos, 4-5 m above ground-level, 25.06.2008; 3 오, Moscow City, Terletsky Park, nest of Turdus pilaris, 4-5 m above ground-level, 25.06.2009, all leg. A. Matyukhin.

REMARKS. This species is quite common in central Russia's parklands and deteriorated forest habitats.

Family Paradoxosomatidae

Strongylosoma kordylamythrum Attems, 1898

MATERIAL. 1 , 1 juv., Stavropol Prov., Kislovodsk, nest of Turdus merula, 4-5 m above ground-level, 14.07.2005; all leg. A. Matyukhin.

REMARKS. This pan-Caucasian species is very common in the Mineral'nye Vody region of Stavropol Province, often even swarming at Zheleznovodsk, Pyatigorsk and Kislovodsk.

\section{Conclusion}

Only relatively few diplopod species appear to populate bird nests in Russia. This is especially true of the nidicolous fauna of central Russia, this being well in agreement with the observations that the European millipede shows an obvious trend to depauperation towards the Ural Mountains to virtually fully decline there [Golovatch, 1992]. In the southern parts of Russia, however, the millipedes encountered in bird nests seem to be more diverse, this being clearly related to the adjacent Caucasus which is long acknowledged as representing one of the major centres of diversification and Tertiary refugia in the entire Ancient Mediterranean. Apparently, much more collecting efforts are necessary to augment and refine the records given in the present pioneering note.

The same actually concerns litter- to ground-dwelling species as well. New, often surprising records of Diplopoda in Eastern Europe are certainly still ahead.

\section{References}

Golovatch S.I. 1992. Some patterns in the distribution and origin of the millipede fauna of the Russian Plain (Diplopoda) // Ber. nat.-med. Vereins Innsbruck, Suppl.10. P.363-373.

Golovatch S.I., Kime R.D. 2009. Millipede (Diplopoda) distributions: A review // Soil Organisms. Vol.81. No.3. P.565-597.

Schubart O. 1934. Tausendfüßler oder Myriapoda I: Diplopoda // Tierwelt Deutschlands. Lfg.28. S.1-318.

Tajovský K., Mock A., Krumpál M. 2001. Millipedes (Diplopoda) in birds' nests // European Journal of Soil Biology. Vol.37. P.321-323. 